\title{
$\begin{array}{lllllllll}S & \mathrm{Y} & \mathrm{M} & \mathrm{P} & \mathrm{O} & \mathrm{S} & \mathrm{I} & \mathrm{U} & \mathrm{M}\end{array}$
}

\section{E PLURIBUS UNUM: IMPACT ENTREPRENEURSHIP AS A SOLUTION TO GRAND CHALLENGES}

\author{
GIDEON D. MARKMAN \\ Colorado State University, Ghent University \\ THEODORE L. WALDRON \\ Texas Tech University \\ PETER T. GIANIODIS \\ Duquesne University \\ MARITZA I. ESPINA \\ St. Ambrose University
}

\begin{abstract}
Insufficiency of research and theory on the relationship between entrepreneurship and grand challenges means that we know little about who engages and what repertoires of actions they take to tackle socioenvironmental challenges that transcend firms, markets, and nations, and what sorts of solutions they create. Drawing on the five articles featured in this symposium-and focusing especially on their protagonists or actors, the actions these actors take, and their achievements - we begin to conceptualize an impact entrepreneurship perspective. Following the tenet of e pluribus unum ("out of many, one") and adhering to the doctrine that diverse, decentralized human effort can improve the world, our impact entrepreneurship perspective refers to the development of solutions to grand challenges, in a financially, socially, and environmentally sustainable fashion. All in all, then, this symposium provides a starting point to discuss, conceptualize, study, interpret, and enrich our understanding of impact entrepreneurship and collective action to address grand challenges.
\end{abstract}

Never doubt that a small group of thoughtful, committed citizens can change the world; indeed, it's the only thing that ever has. - Margaret Mead (quoted in Keys, 1982)

This symposium considers how individuals, whom we collectively call entrepreneurs, resolve human-made socioenvironmental challenges that are so formidable and global that they transcend firms, communities, industries, governments, and nations. These challenges include pollution, poverty, resource inaccessibility, and injustice. Research,

The authors express tremendous gratitude to general editor Phil Phan, an anonymous reviewer, Sophie Bacq, Tom Lumpkin, Saras Sarasvathy, Anusha Ramesh, Jessica Jones, and Jeff York, whose collective comments added immense value and clarity to this introduction. including this symposium, is predicated on the need to understand, attenuate, or, better yet, remedy the affronts of these grand challenges (Dean \& McMullen, 2007; Markman, Russo, Lumpkin, Jennings, \& Mair, 2016; York \& Venkataraman, 2010). While a prevalent view is that either big governments or multinational corporations tackle such challenges-sometimes with financial support from endowments-this symposium offers a complementary view: that disparate individuals, groups, and small ventures can engage, contribute, and bring momentum to the effort needed to tackle grand challenges. Naturally, new developments in science, technology, politics, business, and public policy assist with novel ways of organizing and governing. However, our position is that scholarly research on modalities, especially of the entrepreneurial types, can extend our 
understanding of the "doing well by doing good" dictum beyond the generation of economic returns for firms and their primary stakeholders (Austin, Stevenson, \& Wei-Skillern, 2006; Markman et al., 2016).

Three main streams of research have examined how individuals and firms engage with and resolve socioenvironmental challenges. The first stream, environmental entrepreneurship, links reactions to pollution, climate change, deforestation, and other ecological transgressions with entrepreneurial activity (Dean \& McMullen, 2007; York \& Venkataraman, 2010). The second stream, social entrepreneurship, links efforts to resolve poverty, inequitable opportunities, and other social ills with entrepreneurial approaches (Austin et al., 2006; Dees, 1998). Applied examples include Codecademy, ${ }^{1}$ which teaches coding skills around the world for free, and $\mathrm{EdX},{ }^{2}$ which offers college-level courses worldwide, also for free. The third stream, sustainable entrepreneurship, a hybrid of the first two, links entrepreneurs' efforts to resolve societal and environmental problems (Shepherd \& Patzelt, 2011). The articles comprising this symposium allude to these streams of research, and we elaborate on their themes to expand this topical area. Such effort is needed because of a paradox: Solely on their own, entrepreneurs lack the knowledge, skills, authority, and resources necessary to resolve grand challenges-in fact, these deficiencies, plus the absence of enforcing governance despite the scale of the challenges, should suppress their motivation to engage-and yet these challenges entice collective action from diverse actors (cf. Olson, 1971; Sarasvathy \& Ramesh, this issue).

We reference this paradox to make a point: Research on how governments, big corporations, endowments, and science institutions are fighting grand challenges is critically important, and thus it must continue (Fini, Rasmussen, Siegel, \& Wiklund, 2018; Wright \& Phan, 2018). However, insufficiency of research and theory on the relationships between entrepreneurs (or citizens) and grand challenges means that we know little about who engages and when, and what types of action they take to tackle said challenges plus what sorts of solutions they create. The purpose of this introduction, reflective of and extending the articles comprising the symposium, is to address this deficiency by constructing an impact entrepreneurship perspective.

\footnotetext{
${ }^{1}$ See www.codecademy.com.

${ }^{2}$ See www.edx.org.
}

We define impact entrepreneurship as the development of sustained applications and solutions that collectively address grand challenges to make the world better. Impact entrepreneurs apply economics logic, but they prioritize solving formidable challenges ahead of wealth creation per se. They also use business principles to right environmental, social, and/or economic wrongs and apply science and technology modalities for impact (rather than for enterprise building). That is why for impact entrepreneurs, slaying rivals or dominating markets is less important than solving grand challenges, and why they develop capabilities to deploy sustainable solutions in diverse sectors, especially those traditionally seen to be in the public domain. Just as charity and social entrepreneurship are not equivalent, social and impact entrepreneurship are distinct-the former focuses primarily on social/communal issues, whereas impact entrepreneurship pursues a broader range of purposes. Like sustainable entrepreneurship, impact entrepreneurship too seeks to ameliorate socioenvironmental problems, but its raison d'être is to resolve grand challenges, so it emphasizes impact over new-venture creation, deemphasizing the commercial-noncommercial divide.

Studying the symposium articles, we conceptualize core components of impact entrepreneurshipnotably, in terms of actors, actions, and achievements. We define and elaborate on these constructs shortly, but first it is important to realize that an impact entrepreneurship perspective often applies cross-sector research designs and uses multiple units of analysis rather than a single unit. In fact, the perspective is crystalized by meshing longer-term (Sarason \& Dean) and wide-angle views (Lumpkin \& Bacq) to consider the collective action of disparate individuals (Jones, York, Vedula, Conger, \& Lenox) who use diverse and even nonpredictive processes and modalities to manifest sustainable solutions to grand challenges (Sarasvathy \& Ramesh)—or at the very least facilitate the adaptation to such challenges (Doh, Tashman, \& Benischke).

We will summarize the symposium articles and then make inferences about the actors, actions, and achievements. The symposium articles offer suggestions for future research, so the final section provides a general call to arms for scholars to further the study of impact entrepreneurship modalities.

\section{OVERVIEW OF THE SYMPOSIUM ARTICLES}

The symposium articles cultivate our understanding of how individuals and groups (often referred to 
as entrepreneurs) self-select to address diverse socioenvironmental needs. Extrapolating from the articles, our introduction focuses on transcendent problems loosely called grand challenges (George, Howard-Grenville, Joshi, \& Tihanyi, 2016). Studying how entrepreneurs tackle these challenges is important because, as noted, grand challenges constitute objective, substantive threats to communities and nations and are immune to cultural or moral interpretations. While some express confidence that single or small groups of individuals can resolve grand challenges with sustainable solutions (Hall, Daneke, \& Lenox, 2010), the fact that grand challenges persist and in some cases worsen-plus the lack of theory on this topic-suggests that allocating scholarly attention to this topic is warranted. Our view is that research in entrepreneurship can offer unique insights on resolutions of grand challenges because it considers the development of solutions to market failures-and grand challenges are often associated with market failures (Dean \& McMullen, 2007). The symposium articles (summarized in Table 1) react to this theoretical tension in diverse ways and, when viewed inductively, lay the groundwork for an impact entrepreneurship perspective that explains and predicts engagement for the resolution of grand challenges.

\section{Lumpkin and Bacq}

The article by Lumpkin and Bacq explains how achieving positive and lasting societal impact has become an important raison d'être for nonprofits, social innovators, legislators, corporations, and many others, in areas as diverse as poverty, educational inequality, social injustice, lack of access to health care, and environmental degradation. While past research has pointed to the benefit of collaborative efforts by various community actors, Lumpkin and Bacq's thesis is that because positive societal impact happens across categories of stakeholders, a community view is suitable for understanding social change. Advancing a community unit of analysis, they develop an integrative framework of civic wealth creation (CWC), defined as the generation of social, economic, and communal endowments that benefit communities. The CWC framework directs attention to the intellectual, affective, and material resources and capabilities of a community; it explains how diverse stakeholders interact to create and capture societal impact.

The CWC framework makes several contributions. First, it promotes a more comprehensive perspective on wealth that extends well beyond the narrow definition of financial capital and material possessions. The wealth of a community, Lumpkin and Bacq suggest, is in its human capacities, physical surroundings, cultural endowments, and political will, and in the quality of life and well-being of its members. The CWC framework holds that many societal change efforts are designed to create something more than financial well-being. Second, most research examines phenomena at the individual, group, and/or organizational level of analysis, but the CWC framework suggests an extra-organizational level of analysis. To reflect that, Lumpkin and Bacq call attention to neighborhoods, villages, communities, and cities, which are the focus of most societal change initiatives. A civic level of analysis captures the variety of local settings where the people who are being helped are intimately involved in creating, implementing, and sustaining solutions. Third, instead of applying stakeholder theory logic to a focal organization and its constituencies, the CWC framework emphasizes a more expansive and dynamic view where stakeholders, despite their conflicting positions and diverse motivations, come together to make their community better.

The CWC framework is especially helpful for policy makers and activists because it directs attention to the importance of voluntarism, citizen engagement, and commerce in the discourse surrounding contemporary societal change efforts. Importantly, citizens from the communities being helped are not just passive beneficiaries but essential, active contributors to problem-solving and enterprise-development efforts because of their role in generating and harnessing community support. For CWC, entrepreneurial action is critical for advancing and sustaining societal impact, because it bolsters self-sufficiency and enhances efforts to build legitimacy and attract resources. CWC offers a new perspective to understand positive societal change and guide community members, stakeholders, and entrepreneurially minded individuals on how to come together, aggregate resources, and build communal capacities.

\section{Sarasvathy and Ramesh}

Sarasvathy and Ramesh's article notes that in economics and management research, market failure is often cited as the reason for environmental problems (Cohen \& Winn, 2007), and that the traditional solution to market failure is governmental or collective (political) action. For example, economists see 
TABLE 1

Main Dogmas the Symposium Papers Consider and New Perspectives They Present

\begin{tabular}{|c|c|c|c|}
\hline Paper & Dogma(s) considered vs. new perspectives & Example(s) & Theoretical lenses \\
\hline $\begin{array}{l}\text { Lumpkin \& } \\
\text { Bacq }\end{array}$ & $\begin{array}{l}\text { Dogma: Wealth refers to money and material } \\
\text { possessions, and wealth creation is concerned } \\
\text { with generating financial capital by individuals, } \\
\text { families, and firms. } \\
\text { vs. } \\
\text { Perspective: Wealth is not only financial } \\
\text { accumulation, but also health, happiness, } \\
\text { justice, independence, dignity, etc. At a civic } \\
\text { level of analysis-in neighborhoods, villages, } \\
\text { and communities-civic wealth creation } \\
\text { (CWC) captures the broader sense of well- } \\
\text { being that positive societal initiatives are } \\
\text { seeking. }\end{array}$ & $\begin{array}{l}\text { Efforts of Mondragón Corporation, } \\
\text { Housing Works, and Water } \\
\text { for People to benefit their } \\
\text { communities }\end{array}$ & $\begin{array}{l}\text { - Social change } \\
\text { - Social entrepreneurship } \\
\text { - Stakeholder } \\
\text { (instrumental) }\end{array}$ \\
\hline $\begin{array}{r}\text { Sarasvathy } \\
\text { \& Ramesh }\end{array}$ & $\begin{array}{l}\text { Dogma: It is often assumed that (i) only large } \\
\text { institutions and governments can tackle } \\
\text { common-pool resource problems (e.g., } \\
\text { environmental degradation) and (ii) disparate } \\
\text { individuals don't solve large-scale } \\
\text { environmental challenges. } \\
\text { vs. } \\
\text { Perspective: Individuals self-select to create } \\
\text { sustainable entrepreneurial solutions to } \\
\text { different parts of large-scale common- } \\
\text { pool resource problems using nonpredictive } \\
\text { processes and collective-action principles. }\end{array}$ & $\begin{array}{l}\text { The development and self- } \\
\text { organizing of governance } \\
\text { structures for Los Angeles-area } \\
\text { water basins }\end{array}$ & $\begin{array}{l}\text { - Sustainable } \\
\text { entrepreneurship } \\
\text { - Collective action } \\
\text { - Effectuation }\end{array}$ \\
\hline Jones et al. & $\begin{array}{l}\text { Dogma: Big institutional changes are catalyzed by } \\
\text { powerful centralized actors and regulators. } \\
\text { vs. } \\
\text { Perspective: Multiple types of actors and actions } \\
\text { can-collectively_catalyze and diffuse } \\
\text { institutional changes. }\end{array}$ & $\begin{array}{l}\text { Proliferation of the LEED standard in } \\
\text { the commercial building industry }\end{array}$ & $\begin{array}{l}\text { - Environmental } \\
\text { entrepreneurship } \\
\text { - } \text { Cultural } \\
\text { entrepreneurship } \\
\text { - Institutional } \\
\text { entrepreneurship } \\
\text { - Effectuation }\end{array}$ \\
\hline Doh et al. & $\begin{array}{l}\text { Dogma: Entrepreneurship is about mobilizing and } \\
\text { combining untapped resources to achieve } \\
\text { wealth creation and societal well-being. } \\
\text { vs. } \\
\text { Perspective: Entrepreneurs can also initiate, } \\
\text { facilitate, and edify cross-sector partnerships } \\
\text { that improve adaptation to grand environmental } \\
\text { challenges. }\end{array}$ & $\begin{array}{l}\text { Governance of partnerships between } \\
\text { EEAB and INAP, CafeDirect and } \\
\text { GIZ, and Oxfam and Swiss Re }\end{array}$ & $\begin{array}{l}\text { - Environmental } \\
\text { entrepreneurship } \\
\text { - Cross-sector } \\
\text { partnerships }\end{array}$ \\
\hline $\begin{array}{l}\text { Sarason } \\
\text { \& Dean }\end{array}$ & $\begin{array}{l}\text { Dogma: Once acquired, sustainable } \\
\text { entrepreneurial firms invariably sacrifice their } \\
\text { socioenvironmental missions and activities. } \\
\text { vs. } \\
\text { Perspective: Acquired ventures can infuse } \\
\text { sustainability activities into acquirers, and } \\
\text { institutionally, even small initial changes can } \\
\text { bring big economic, political, and cultural } \\
\text { changes. }\end{array}$ & $\begin{array}{l}\text { When Danone acquired White Wave } \\
\text { and Coca-Cola acquired Honest } \\
\text { Tea, pundits criticized the social } \\
\text { enterprises for selling out. } \\
\text { However, these social enterprises } \\
\text { actually infused the incumbents } \\
\text { with their social missions. }\end{array}$ & $\begin{array}{l}\text { - Sustainable } \\
\text { entrepreneurship } \\
\text { - Institutional change } \\
\text { - Structuration }\end{array}$ \\
\hline
\end{tabular}

environmental problems as collective action problems-situations where individuals would be better off cooperating but fail to do so because of conflicting interests and diverging motivations
(Olson, 1971; Ostrom, 2015). Management scholars emphasize the role that organizations and entrepreneurs play in tackling such problems (Shepherd \& Patzelt, 2011; Shrivastava, 1995), but the domain has 
yet to explain how individuals self-select to solve complex sustainability issues that require collective action (cf. Battilana, Leca, \& Boxenbaum, 2009). This gap between individual action and processes of collective action with political and economic frameworks raises a question: In the absence of centralized governance, how do individuals interact and develop sustainable solutions to collective-action problems? To address this question, Sarasvathy and Ramesh reanalyze the historical case of how water rights issues in the Los Angeles basin came to be resolved. That analysis enables them to build a process model that integrates collective-action theories from economics and entrepreneurship to develop an effectual model of collective action.

Although society often expects governments to have oversight for resolving grand challenges, reality shows that many of these challenges persist. Different organizational forms-e.g., for-profit, nonprofit, and social ventures-are not enough either, but they seem to introduce micro-modalities (e.g., new products and technologies) and find macrosolutions (e.g., institution-building and social movements) that inform governmental regulations. Given the scale, urgency, and complexity of grand challenges, plus the creative entrepreneurial solutions to such problems, it is important to develop a rigorous and more useful framework to guide scholars and policy makers. Studying the conditions under which individuals overcome tragedies of the commons, and combining effectuation principles (Sarasvathy, 2009) with Ostrom's principles for managing the commons (Ostrom, 2010, 2015), Sarasvathy and Ramesh explain how individuals who self-select into collective action can address seemingly irredeemable tragedies and turn them into new and more sustainable solutions.

Their study challenges strong boundary conditions; it neither adheres to limiting assumptions about the environment nor does it presuppose that individuals must have specific personality traits, skills, or even capabilities. Instead it offers a guide to action for all sorts of environments and individuals who self-select into collective-action processes based on Ostrom's design principles and effectual heuristics. Their framework is useful for policy makers as it is teachable, testable, and scalable and offers concrete mechanisms that stakeholders can use in the face of complex environmental challenges. These mechanisms can serve as a dashboard that policy makers can put to work through controlled experiments and targeted interventions to jumpstart new entrepreneurial action and foster and maintain ongoing initiatives already on the ground, leading to market-augmenting rather than market-hindering regulations.

\section{Jones, York, Vedula, Conger, and Lenox}

The article by Jones, York, Vedula, Conger, and Lenox also notes that corporations and government agencies are often viewed as the primary agents of institutional change (Eccles, Ioannou, \& Serafeim, 2014), but that in many sustainability contexts, no single actor has the scale, skills, resources, or even the authority to be the catalytic leader. Studying an illustrative process-the voluntary Leadership in Energy and Environmental Design (LEED) certification in the commercial construction industry-Jones and her colleagues explain how various entrepreneurial actions create new practices and then foster the adoption of, build legitimacy for, and eventually commercialize sustainable, industry-wide practices. Their article challenges the oft-cited reliance on heroic actors-“institutional entrepreneurs"-who seem to singlehandedly and swiftly change big institutions (Battilana et al., 2009; Garud \& Karnøe, 2003; Lounsbury, 2008). Instead, they explain how industries move gradually toward sustainable practices through the efforts of multiple, self-selected actors rather than a centralized and well-governed force (Ostrom, 2010, 2015). As many environmental challenges do not lend themselves to self-regulatory solutions (Ansari, Wijen, \& Gray, 2013; Hiatt, Grandy, \& Lee, 2015), explaining how diverse actors foster an evolution toward environmental responsibility is important (Hall et al., 2010; York, Vedula, \& Lenox, 2018).

A unique feature of the article is the authors' process, a longitudinal view, which theorizes four phases in an industry transition toward sustainability: (1) initiation through new practice creation, (2) voluntary adoption of new practices and standards, (3) legitimation of new practices through framing, and (4) commercialization of new practices through new market entries and alternatives. Their perspective contributes to the environmental sustainability and institutional literatures in two main ways. First, as noted, they show how even in the absence of centralized or authoritative governance, the actions of multiple, sometimes unrelated, actors can coalesce and mobilize an industry to adopt sustainable practices. Second, they show that initiating, adopting, legitimating, and/or commercializing a new practice requires different forms of entrepreneurial action at different evolutionary stages. 
Interestingly, their study demonstrates how sustainability, entrepreneurship, and institutional theories can assist in revealing the four phases of an industry's transition to environmentally beneficial practices. This is a critical area for management scholars and for policy makers to explore given the need for multipronged engagement with and reaction to environmental challenges. Further, policy makers would do well to consider entrepreneurial action when designing legal structures that enhance or constrain environmentally focused practices. Their perspective is consistent with ours, that the actions of diverse and often disconnected actors can shape industry practices even without centralized enforcement and governance mechanisms.

\section{Doh, Tashman, and Benischke}

Doh, Tashman, and Benischke too contend that we lack research on organizational forms and institutional mechanisms for dealing with grand challenges. Doh and his colleagues propose that collective environmental entrepreneurship (CEE) is a mechanism for coalescing cross-sector actors for assisting with the adaptation to these challenges. A main premise of CEE is that cross-sectoral partnerships-e.g., among businesses, government agencies, and nongovernmental organizations (NGOs)—can accelerate the piloting and commercialization of solutions to grand challenges. The logic behind CEE is intuitive: Actors from dissimilar sectors accumulate distinct capabilities for fulfilling different functions, and these capabilities can be complementary in diverse contexts. For example, business enterprises excel at capital formation and innovation and are best suited to commercializing solutions to these challenges, whereas governments provide the political skills and regulatory authority to pave the way for implementing these solutions. Understanding how grand challenges and solutions to said challenges affect societies, the authors suggest that NGOs represent the interests of communities and the commons, so they often mobilize grassroots support for piloting and implementing new initiatives. Further, through foundations and ties with academia, they can offer critical technical expertise to CEE efforts.

CEE partnerships require interest-alignment and trust-building mechanisms because despite their complementary capabilities, business, government, and civil society have different motivations and time horizons to address grand challenges. Subjected to a relatively short-term orientation, businesses are primarily concerned with protecting their resources, value chains, and revenue streams and the interests of investors. Governments are especially concerned with fulfilling their administrative obligations in providing public goods, including the rule of law and health and education infrastructures, and in making their goods resilient to grand challenges. Representing civil society, NGOs are concerned with protecting vulnerable communities. Given these varied interests, CEE partnerships are prone to goal conflicts that can inhibit sectors from developing the fruitful relationships necessary for the work they are undertaking.

Focusing on how to mitigate such conflicts, Doh, Tashman, and Benischke propose governance mechanisms for cross-sectoral partnerships that align the interests of multisector partners and enable them to develop mutually beneficial CEE initiatives. The authors stress that the governance mechanisms for adapting to these challenges value ecological systems, establish coordinated decision-making authority across levels of governance, and distribute risks across partners responsible for investing in and provisioning public goods. Their article details how these mechanisms can help resolve some of the inherent conflicts that often characterize CEE partnerships and illustrates them through several case vignettes.

\section{Sarason and Dean}

The Sarason and Dean article is more removed from grand challenges per se, but it is applicable to impact entrepreneurship as it examines the process by which small entrepreneurial firms pass socioenvironmental values to large and dominant acquirers. Acquisitions, especially when large firms acquire socially or environmentally focused firms, raise important questions about the transferability of socioenvironmental missions from acquired to acquiring firms (Brueller, Carmeli, \& Markman, 2018; Gasparro, 2017; Lee \& Jay, 2015). The popular interpretation of such acquisitions is rather simplistic-i.e., the entrepreneurs are "selling out" -and assumes an inevitable deterioration of socioenvironmental practices post-acquisition (Austin \& Leonard, 2008; Edmondson, 2014; Teather, 2006). Sarason and Dean explore whether, and to what extent, this dogma holds true; specifically, they probe the actions entrepreneurs undertake to maintain, channel, and even expand their socioenvironmental missions after the acquisition. Their study also explains how acquired companies transfer socioenvironmental 
values despite institutional constraints, such as acquirers' motivation for and commitment to financial gain.

Reviewing acquisitions of sustainable companies in the natural and organic food industry through interviews, case studies, scholarly articles, and media reports, Sarason and Dean counter the "selling out" view by offering a "selling in" perspective. They coin useful labels such as lost battles (the diminishment or loss of sustainable mission), Trojan horses (when sustainable values infiltrate the acquiring firms), open gates (when acquirers embrace the sustainable values and practices of their targets), and wars won (when acquirers go through substantive, boundaryspanning structural change to promote sustainable values). Their study offers a new perspective on the acquisition of mission-based firms by incumbents who, at the time, prioritized financial performance ahead of all else.

The article reveals three overarching conclusions. First, the sale of socioenvironmental companies deviates quite often from the popular perception of selling out. Rather, the authors share substantive examples of contractual, legal, and other enforceable arrangements to privilege, protect, and sustain socioenvironmental practices after an acquisition. Second, there appears to be an increase in the sophistication of structures in place to ensure that the socioenvironmental missions of firms extend into and influence their acquirers. These include changes in the way that entrepreneurs and acquirers frame these deals, contractual mechanisms designed to ensure continued focus on sustainability, new legal forms of organization, and increased influence on the part of the ventures. Third, the transferability of socioenvironmental values stems from the engagement and interactions of multiple parties. In addition to the acquirers and entrepreneurs, consumers remain engaged by their appreciation of responsible products, certifications, and missions. Engagement also comes from legislators who support Benefit Corporation (B-Corp) laws, policies for renewable energy, and the Organic Foods Production Act; investors who seek impact; and other stakeholders who advocate for B-Corp certification and standards. It is worth noting that organizational culture is not part of their study, but Sarason and Dean show that even when small firms get subsumed and dissolved by larger acquirers, their social values can-under certain conditions-live on and even displace acquirers' dominant values.

In sum, Sarason and Dean explain that entrepreneurs can expand their impact by imbuing and impregnating large acquirers with socioenvironmental values, goals, and practices.

\section{AN IMPACT ENTREPRENEURSHIP PERSPECTIVE}

The symposium articles represent diverse views, contexts, and orientations, emphasizing selfselected, voluntary engagement, often based on collective action that creates commercial and noncommercial solutions to formidable challenges. We posit that such scholarship assists with the development of an impact entrepreneurship perspective. Following the e pluribus unum tenet ("out of many, one") and adhering to the doctrine that diverse, decentralized human effort can improve the world, impact entrepreneurship is about the development of modalities for addressing grand challenges in a financially sustainable fashion. To further the topic, we have consolidated, organized, and synthesized the content of the articles along three key dimensions: the main actors, their actions, and their achievements. We have also discerned the articles' themes and main constructs, and as Table 2 shows, we looked for patterns in the assumptions, particularly those of conceptual utility relevant to impact entrepreneurship.

\section{Impact Entrepreneurship Actors: Collectives}

Implicitly or explicitly, the focal actors in the symposium articles are often made of collectives. We conceptualize collectives as encompassing private agents (individuals, entrepreneurs, enterprises, nonprofits), public agencies (governments), and civil society entities (NGOs) whose engagement aims to alleviate market, social, or environmental failures that cause grand challenges. Each type of collective actor brings distinct-yet complementary-logics and competencies (Doh et al.; Lumpkin \& Bacq). Collectives vary in type, size, skill set, and composition, with examples including consumers and free enterprises (Sarason \& Dean); community stakeholders and collaborators (Lumpkin \& Bacq); individuals and/or industry stakeholders (Jones et al.; Sarasvathy \& Ramesh); and government agencies, science parks and research institutions, and crosssector partners (Doh et al.), among others. The point is this: Collectives-as opposed to either a single person, a corporation, or a government-seem to self-select to engage and in due time build momentum and institutional support to address grand challenges (Jones et al.; Sarasvathy \& Ramesh). 
TABLE 2

Symposium Papers' Representations of the Core Components of Impact Entrepreneurship

\begin{tabular}{|c|c|c|c|}
\hline Paper & $\begin{array}{l}\text { Actor(s): The } \\
\text { entrepreneurial collectives }\end{array}$ & $\begin{array}{l}\text { Action(s): Behavioral } \\
\text { repertoire/objectives }\end{array}$ & $\begin{array}{l}\text { Achievement(s): Sustainable } \\
\text { innovation systems }\end{array}$ \\
\hline $\begin{array}{l}\text { Lumpkin \& } \\
\text { Bacq }\end{array}$ & $\begin{array}{l}\text { - Community members } \\
\text { - Regimes of support } \\
\text { - Enterprises }\end{array}$ & $\begin{array}{l}\text { - Engaged participation } \\
\text { - Collaborative innovation } \\
\text { - Resource mobilization }\end{array}$ & - Creation of civic wealth \\
\hline $\begin{array}{l}\text { Sarasvathy \& } \\
\text { Ramesh }\end{array}$ & $\begin{array}{l}\text { - Entrepreneurs } \\
\text { - Issue stakeholders }\end{array}$ & $\begin{array}{l}\text { - Means evaluation } \\
\text { - Option evaluation } \\
\text { - Stakeholder interaction } \\
\text { - Stakeholder commitment } \\
\text { - Collective mobilization }\end{array}$ & $\begin{array}{l}\text { - Formation of collectives } \\
\text { - Creation of sustainable solutions } \\
\text { to socioenvironmental problems }\end{array}$ \\
\hline Jones et al. & $\begin{array}{l}\text { - Entrepreneurs } \\
\text { - Nonprofits } \\
\text { - Corporations } \\
\text { - Governments }\end{array}$ & $\begin{array}{l}\text { - Initiation } \\
\text { - Adoption } \\
\text { - Legitimation } \\
\text { - Commercialization }\end{array}$ & $\begin{array}{l}\text { - Diffusion of environmentally } \\
\text { sustainable industry practices }\end{array}$ \\
\hline Doh et al. & $\begin{array}{l}\text { - Public actors } \\
\text { - Private actors } \\
\text { - Civil society actors }\end{array}$ & $\begin{array}{l}\text { - Resolve focus conflicts } \\
\text { - Resolve scale conflicts } \\
\text { - Resolve time horizon conflicts }\end{array}$ & $\begin{array}{l}\text { - Governance of partnerships } \\
\text { - Creation of sustainable solutions } \\
\text { to environmental problems }\end{array}$ \\
\hline $\begin{array}{l}\text { Sarason \& } \\
\text { Dean }\end{array}$ & $\begin{array}{l}\text { - Entrepreneurial firms } \\
\text { - Incumbent/acquiring firms } \\
\text { - Industry stakeholders }\end{array}$ & $\begin{array}{l}\text { - Lost battles } \\
\text { - Trojan horses } \\
\text { - Open gates } \\
\text { - Wars won }\end{array}$ & $\begin{array}{l}\text { - Post-acquisition persistence } \\
\text { of entrepreneurial firms' } \\
\text { socioenvironmental missions }\end{array}$ \\
\hline
\end{tabular}

Evidently, impact entrepreneurship motivates engagement and interactions of private, public, and civil society actors.

Though the symposium articles similarly emphasize the role of collectives, their focus on and conceptions of the role of each of these collectives diverge. Some articles portray entrepreneurs as influential in establishing, setting, and executing the objectives of collectives, exemplified by Sarason and Dean, who explain that acquired firms can and do proliferate their socioenvironmental values. Other articles portray entrepreneurs as relatively equivalent to many other actors in terms of their influence over objectives, which evolve over time as the collective matures. For instance, Lumpkin and Bacq suggest that three types of stakeholders, roughly equivalent to public, private, and civil society actors, all play important roles in communitybased collectives. Embedded in these different conceptions of the entrepreneur-collective nexus is the view that because they influence and are being influenced by their environments, actors seek institutional change (Suddaby, Bruton, \& Si, 2015). We acknowledge that resolutions of grand challenges often start and/or end with institutional change, but we argue that actors' higher-order aim is to engage and resolve grand challenges.

We direct attention to the concept of collectives to bring awareness to actors whose joint action-even if neither well-coordinated nor governed-is at the forefront of impact entrepreneurship. Though it is intuitively clear that collectives consist of diverse actors, many actors engage with hardly any awareness of, let alone coordination with, other actors. For example, the U.S. Open Government Initiatives ${ }^{3}$ provide public access to massive amounts of government data $(229,831$ data sets on agriculture, climate, ecosystems, education, energy, health, local government, ocean, public safety, science, etc.), while Google's for-profit Sidewalk Labs ${ }^{4}$ uses technology to solve chronic urban infrastructure problems (e.g., inefficient and unpredictable urban transportation systems). Impact entrepreneurship proposes that when business enterprises, governments, and NGOs cooperate (and compete) across their silos, they can significantly improve the infrastructure and welfare of communities and nations.

Interestingly, collectives may engage even in the absence of centralized governance, which raises questions about the composition and configuration of collectives as well as about modalities to resolve conflicting priorities. Also, different conceptions of collectives may shed light about the type(s) of actors likely to lead the formation and direction of these collectives at different phases and the power

\footnotetext{
${ }^{3}$ See www.open.usa.gov.

${ }^{4}$ See www.sidewalklabs.com.
} 
dynamics (e.g., bargaining and negotiation) at play during such processes. For example, when collectives form organically, are there catalysts or triggering conditions that motivate diverged collectives to coalesce? Finally, the premise that collectives are reflexive inspires attention to how variation in the reflexivity of actors shapes their engagement and interactions. Actors-i.e., entrepreneurs, government entities, and NGOs-need to resolve tensions among their respective tendencies to facilitate institutional change.

\section{Impact Entrepreneurship's Action Repertoires}

Just as companies combine diverse resources, capabilities, and business models to create and capture wealth, the symposium articles show how collectives use repertoires of actions to tackle transcendent challenges. We view an action repertoire as purposeful acts, dependent and/or independent, that in combination ameliorate or even resolve grand challenges. For example, using effectuation and collective action principles, Sarasvathy and Ramesh describe the rich repertoire of actions that individuals took to manage the groundwater basins beneath the Los Angeles metropolitan area. Sarason and Dean detail action repertoires that involve the selling of social-mission firms to proliferate socioenvironmental values and objectives in acquiring organizations. Jones et al. explain how private individuals formed the U.S. Green Building Council (USGBC) to consider, create, and diffuse environmentally beneficial practices in the building industry; the action repertoire in their study includes the initiation of new standards and practices, voluntary adoption (e.g., LEED certification), and efforts to legitimize and proliferate said standards. Though the articles vary in the types of repertoires, they emphasize how the confluence and sequence of actions that characterize impact entrepreneurship are not always well coordinated, linear, or even ex ante predictive. These attributes of impact entrepreneurship explain why such action repertoires are distinct from the actions of more traditional enterprises whose drivers are often near-term success, operational efficiency, consumerism, growth, and private wealth creation, to name a few.

The action repertoires in the symposium articles seem to favor voluntarism and self-selection over centralized governance, but they adhere to different ontological foundations. For instance, some articles attribute the actions of entrepreneurial collectives to participants who gradually grew their influence
(Jones et al.; Sarason \& Dean; Sarasvathy \& Ramesh), whereas other articles refrain from making such attributions and treat actions as organic occurrences (Doh et al.; Lumpkin \& Bacq). Additionally, some articles portray the actions of entrepreneurial collectives as effectual, serving to secure resources and co-create solutions with self-selected stakeholders (e.g., Jones et al.; Sarasvathy \& Ramesh). Others portray the action repertoire as more causal, contributing to the attainment of predetermined objectives (e.g., Lumpkin \& Bacq; Sarason \& Dean).

Finally, the articles differ in their conceptions of the nexus of actions and opportunities. Some articles treat actions as effectual, presuming that action repertoires enable collectives to create, more than discover, opportunities for addressing grand challenges. Other articles treat actions as more causal, presuming that actions enable collectives to discover, more than create, these opportunities. Current scholarship sees the two as a dichotomy with an irreconcilable theoretical tension within it, but our view is that future research will unearth boundary conditions and reveal contexts under which each perspective is more useful in meeting grand challenges. Naturally, when collective action is based on self-selection and voluntarism, it often unites actors around the challenges their community is facing.

\section{Achievements: Viable Steps Toward or Solutions to Grand Challenges}

For the most part, the symposium articles converge on commercial and noncommercial sustainable solutions (or steps toward solutions) to challenges. The solutions (or their associated subsolutions) take diverse forms, including the creation of new organizations, products, services, and collaborations (Doh et al.; Lumpkin \& Bacq; Sarasvathy \& Ramesh); new industry standards and practices (Jones et al.); and even contractual obligations aiming to preserve and proliferate socioenvironmental values (Sarason \& Dean). Extrapolating from these studies, it is clear that an impact entrepreneurship perspective focuses on voluntary, systemic, and sustainable solutions, rather than well-governed, isolated, and transitional ones.

The ultimate achievement is to eradicate the negative effects foundational to grand challenges; however, the studies recognize that other milestones are also important. Conceptually, impact entrepreneurship fulfills several functions, and for brevity we focus on the ability to challenge big dogmas, alter institutional fields, and deviate from industry logic (cf. 
Battilana et al., 2009). Following an e pluribus unum thinking to stimulate more pluralistic wealth creation modalities, impact entrepreneurship requires-in due time-convergence between and collaboration among communities, enterprises, and regimes of support that often follow diverging logics of action and seek competing objectives (Lumpkin \& Bacq). While material wealth creation is still critically valid, a more holistic application of wealth creation and appropriation offers a complementary modality to create vibrant economies with social and environmental endowments (e.g., income enhancement; access to food, health, and education; and pollution reduction).

Given the magnitude of grand challenges, the unpredictive nature of collective action, and the promise of cross-sectoral partnerships, the meshing of logic and capabilities is essential if collectives are to be formed and thus adaptations to or solutions for grand challenges can be conceived (Doh et al.; Sarasvathy \& Ramesh). In other circumstances, actors not affiliated with entrepreneurial collectives may alter institutional environments in response to emerging innovation systems, such as through the introduction of alternative business models and voluntary industry standards (Jones et al.). These inferences suggest once again that to address grand challenges, impact entrepreneurship must (a) catalyze institutional change and (b) broker collaboration among cross-sectoral institutions and selfselecting, independent stakeholders (Lumpkin \& Bacq).

\section{DISCUSSION AND CONCLUSION}

The need to address grand challenges has inspired and frustrated humanity for a long time (Churchman, 1967). Like the general population, scholars look to governments to address the world's biggest problems-pollution, poverty, human trafficking, etc.- - yet governments' record on tackling such intractable problems is mixed at best. And while we move toward sustainable solutions on some issues, other problems are worsening and new challenges emerge. Naturally, government engagement has played and will continue to play a critical role, but we suggest that impact entrepreneurship is a complementary modality for addressing these challenges in a financially, socially, and environmentally sustainable fashion.

Consolidating, organizing, synthesizing, and clarifying the symposium articles, we conceptualized core components of an impact entrepreneurship perspective. The fact that entrepreneurial collectives (actors) exploit diverse action repertoires (actions) to develop sustainable solutions to grand challenges (achievements) hints that impact entrepreneurship offers a distinct conceptual lens. Interestingly, it seems that the development of sustainable solutions to grand challenges will not arise from the field of management-or any single discipline-in isolation. We expect there to be a recursive relationship across disciplines, and much of the research highlighted in this symposium integrates mainstream entrepreneurship theory (e.g., effectuation) with imported theory from the wider management discipline, but other perspectives are called into action (e.g., sociology, economics, public policy, and environmental sciences, to name a few). As noted, this integration of theoretical traditions to advance an impact entrepreneurship perspective requires multidisciplinary research teams with significant breadth and depth of knowledge to understand, integrate, and predict the complex interactions underlying solutions to grand challenges.

Can collective action create momentum and bring resolutions to grand challenges in the absence of government intervention? As noted, the answer, according to Ostrom $(2010,2015)$ and Sarasvathy and Ramesh, is a resounding yes, and we add that often government intervention takes cues from and follows the collective action of private citizensalthough at times the lag time can be decades. For example, in the United States, the impetus to improve working conditions, stop child labor, increase wages, reduce working hours, and afford health and education benefits came not from the government but from the collective action of people, with the earliest recorded labor-rights strike occurring in 1768 (when New York journeymen tailors protested a wage reduction). And government intervention in the form of human rights policies and labor laws started appreciably later-the U. S. Department of Labor was created only in 1913, and the International Labor Organization was founded in 1919 and became the first specialized agency of the United Nations in 1946.

Of course, the debate is not whether collective action, private enterprise, or government intervention offers the best solution to grand challenges, but to reveal the conditions under which impact entrepreneurship and its collective action can accelerate edifying engagement from government and corporations. To enrich our understanding of impact entrepreneurship, it would be interesting to look at the actors, actions, and achievements in the development of sustainable solutions to not only environmental impact, but urban poverty and the 
financial infrastructure of social innovation, among other challenges (Espina, Phan, \& Markman, 2018).

In closing, impact entrepreneurship's raison d'être is to address grand challenges through sustained solutions and make the world better. Resolving grand challenges and enhancing the well-being of people and planet requires scholars to expand the definition of wealth, engagement, accountability, and responsibility; to broaden the roles that individuals, communities, corporations, and governments play; and to develop more diverse indicators and measurements to capture data and guide research and practice on modalities to balance the relationship between people, business, and Earth. To paraphrase David Korten (1990), the deployment and practice of impact entrepreneurship are complex, but the paradigm is not: Remove trade-offs (e.g., planet/people, community/individuals, liberty/ security, freedom/safety, etc.) and prioritize the sustainability of Earth and its inhabitants, develop a dashboard of measurable data and indicators to guide impact entrepreneurship scholarship and purposedriven practice to advance public policies, and protect the common good-and adjust as we learn more. The articles in this symposium show, as does the quote from Margaret Mead at the beginning of this introduction, that there is no need to wait for others (e.g., either governments or enterprises) to act first.

\section{REFERENCES}

Ansari, S., Wijen, F., \& Gray, B. (2013). Constructing a climate change logic: An institutional perspective on the "tragedy of the commons." Organization Science, 24(4), 1014-1040.

Austin, J. E., \& Leonard, H. B. D. (2008). Can the virtuous mouse and the wealthy elephant live happily ever after? California Management Review, 51, 77-102.

Austin, J. E., Stevenson, H., \& Wei-Skillern, J. (2006). Social and commercial entrepreneurship: Same, different, or both. Entrepreneurship Theory and Practice, 30(1), $1-22$.

Battilana, J., Leca, B., \& Boxenbaum, E. (2009). How actors change institutions: Towards a theory of institutional entrepreneurship. Academy of Management Annals, 3, 65-107.

Brueller, N. N., Carmeli, A., \& Markman, G. D. (2018). Linking merger and acquisition strategies to postmerger integration: A configurational perspective of human resource management. Journal of Management, 44, 1793-1818.

Churchman, C. W. (1967). Wicked problems. Management Science, 14, 141-146.
Cohen, B., \& Winn, M. I. (2007). Market imperfections, opportunity and sustainable entrepreneurship. Journal of Business Venturing, 22, 29-49.

Dean, T. J., \& McMullen, J. S. (2007). Toward a theory of sustainable entrepreneurship: Reducing environmental degradation through entrepreneurial action. Journal of Business Venturing, 22, 50-76.

Dees, J. G. (1998). Enterprising nonprofits. Harvard Business Review, 76, 54-69.

Eccles, R. G., Ioannou, I., \& Serafeim, G. (2014). The impact of corporate sustainability on organizational processes and performance. Management Science, 60(11), 2835-2857.

Edmondson, B. (2014). Ice cream social: The struggle for the soul of Ben \& Jerry's. San Francisco: BerrettKoehler Publishers.

Espina, M. I., Phan, P. H., \& Markman, G. D. (Eds.). (2018). Social innovation and sustainable entrepreneurship. Cheltenham, UK: Edward Elgar Publishing.

Fini, R., Rasmussen, E., Siegel, D., \& Wiklund, J. (2018). Rethinking the commercialization of public science: From entrepreneurial outcomes to societal impacts. Academy of Management Perspectives, 32, 4-20.

Garud, R., \& Karnøe, P. (2003). Bricolage versus breakthrough: Distributed and embedded agency in technology entrepreneurship. Research Policy, 32(2), 277-300.

Gasparro, A. (2017, February 18). Big food looks to startups for ideas, innovation. Wall Street Journal. Retrieved from https://www.wsj.com/articles/big-food-looksto-startups-for-ideas-innovation-1487327410

George, G., Howard-Grenville, J., Joshi, A., \& Tihanyi, L. (2016). Understanding and tackling societal grand challenges through management research. Academy of Management Journal, 59, 1880-1895.

Hall, J. K., Daneke, G. A., \& Lenox, M. J. (2010). Sustainable development and entrepreneurship: Past contributions and future directions. Journal of Business Venturing, 25(5), 439-448.

Hiatt, S. R., Grandy, J. B., \& Lee, B. H. (2015). Organizational responses to public and private politics: An analysis of climate change activists and US oil and gas firms. Organization Science, 26(6), 1769-1786.

Keys, D. (1982). Earth at omega: Passage to planetization. Wellesley, MA: Branden Publishing Co.

Korten, D. C. (1990). Getting to the 21st century: Voluntary action and the global agenda. Sterling, VA: Kumarian Press.

Lee, M., \& Jay, J. (2015). Strategic responses to hybrid social ventures. California Management Review, 57, 126-148.

Lounsbury, M. (2008). Institutional rationality and practice variation: New directions in the institutional analysis of practice. Accounting, Organizations and Society, 33(4-5), 349-361. 
Markman, G. D., Russo, M., Lumpkin, G. T., Jennings, P. D., \& Mair, J. (2016). Entrepreneurship as a platform for pursuing multiple goals: A special issue on sustainability, ethics, and entrepreneurship. Journal of Management Studies, 53, 673-694.

Olson, M. (1971). The logic of collective action: Public goods and the theory of groups. Cambridge, MA: Harvard University Press.

Ostrom, E. (2010). Beyond markets and states: Polycentric governance of complex economic systems. Transnational Corporations Review, 2, 1-12.

Ostrom, E. (2015). Governing the commons: The evolution of institutions for collective action. Cambridge, UK: Cambridge University Press.

Sarasvathy, S. D. (2009). Effectuation: Elements of entrepreneurial expertise. Cheltenham, UK: Edward Elgar Publishing.

Shepherd, D. A., \& Patzelt, H. (2011). The new field of sustainable entrepreneurship: Studying entrepreneurial action linking "what is to be sustained" with "what is to be developed." Entrepreneurship Theory and Practice, 35, 137-163.

Shrivastava, P. (1995). The role of corporations in achieving ecological sustainability. Academy of Management Review, 20, 936-960.

Suddaby, R., Bruton, G. D., \& Si, S. X. (2015). Entrepreneurship through a qualitative lens: Insights on the construction and/or discovery of entrepreneurial opportunity. Journal of Business Venturing, 30(1), 1-10.

Teather, D. (2006, March 18). Roddick nets $£ 130 \mathrm{~m}$ from Body Shop sale. Guardian. Retrieved from http://www.theguardian.com/business/2006/mar/18/ highstreetretailers.retail

Wright, M., \& Phan, P. (2018). The commercialization of science: From determinants to impact. Academy of Management Perspectives, 32, 1-3.
York, J. G., \& Venkataraman, S. (2010). The entrepreneurenvironment nexus: Uncertainty, innovation, and allocation. Journal of Business Venturing, 25, 449463.

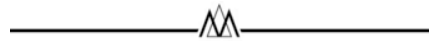

Gideon D. Markman (gid.markman@gmail.com) is a professor of strategy, entrepreneurship, and sustainable enterprise at Colorado State University and Ghent University in Belgium. His research focuses on competitive dynamics; market entry; the sharing economy; and social, environmental, sustainable, and impact entrepreneurship. He is a founder of the Sustainability, Ethics \& Entrepreneurship (SEE) Conference.

Theodore L. Waldron (theodore.waldron@ttu.edu) earned his Ph.D. from the University of Georgia and serves as an associate professor of sustainable strategy in the Jerry S. Rawls College of Business at Texas Tech University. His research examines intersections between competitive dynamics, social movements, and entrepreneurship.

Peter Gianiodis (gianiodisp@duq.edu) is the inaugural holder of the Merle E. Gilliand Professorship in Entrepreneurial Finance at the Palumbo Donahue School of Business at Duquesne University. His research focuses on competitive dynamics and market entry, university technology commercialization, sustainable entrepreneurship, and social enterprising.

Maritza I. Espina (espinamaritza@sau.edu) is dean of the College of Business and a professor of strategy and entrepreneurship at St. Ambrose University in Davenport, Iowa. The integration of business and technology has been a common thread through her research projects, including the intersections of intellectual property, entrepreneurship, and social innovation. 
Copyright of Academy of Management Perspectives is the property of Academy of Management and its content may not be copied or emailed to multiple sites or posted to a listserv without the copyright holder's express written permission. However, users may print, download, or email articles for individual use. 